\title{
Formulate gastroretentive floating bioadhesive drug delivery system of nizatidine by direct compression technique
}

\author{
Sravya V*, Suresh Kumar P, Jagannath Patro V, Sunitha Ch \\ Department of Pharmaceutics, Browns College of Pharmacy, Khammam, Telangana, India
}

Received: 15-11-2021 / Revised Accepted: 19-12-2021 / Published: 02-01-2021

\begin{abstract}
Nizatidine is a gastroprotective drug with a short biological half-life and narrow absorption window. This study aimed at developing floating tablets of nizatidine using various HPMC viscosity grades, namely K4M, K15M, Carbopol 934P, Sodium alginate and sodium carboxy methyl cellulose. Directly compressed tablets revealed an excellent uniformity in hardness, thickness and weight and nizatidine was evenly distributed within the matrix floating tablets. Buoyancy study revealed the tablets remain buoyant for more than $12 \mathrm{~h}$. Among all the formulations, F12 formulation containing 3:1 ratio of HPMC K15M and Carbopol 934P was found to be promising, which showed a floating lag time less than $5 \mathrm{~min}$ and floating duration of more than 12 hours. It showed constant drug release up to 12 hours and good bio adhesion strength. All the designed formulations displayed zero order release kinetics and drug release follows non-Fickian diffusion mechanism.
\end{abstract}

Keywords: Nizatidine, Hydroxy propyl methyl cellulose, Gastro-retentive, Floating, Carbopol

\section{INTRODUCTION}

In recent years, gastric retentive drug delivery systems are more effective drug delivery system. When, some of the drugs were formulated as controlled release dosage forms they can't attain the sufficient bioavailability and effective plasma level due to its less gastro intestinal transit time ${ }^{1}$. By retention of such drugs in the stomach, we can prolong the overall gastrointestinal transit time and increase the bioavailability. This would be particularly valuable for the drugs that exhibit an absorption window in the upper part of the small intestine $^{2}$. There are a number of approaches that can be used to prolong gastric retention time, such as floating drug delivery systems, swelling and expanding systems, polymeric bio-adhesive systems, and modified shape systems, high density systems and other delayed gastric emptying devices. From the formulation considerations, FDDS appears to be the most flexible and potent approach to prolong gastric residence time of drug $^{3}$.

Nizatidine [N-2-2-(dimethylamino) methyl]-4thiazolyl] methyl thio] ethyl]-N'-methyl-2-nitro-1, 1-ethenediamine] is competitive, reversible inhibitor of the histamine $\mathrm{H}_{2}$ receptors of the gastric acid secreting cells ${ }^{4}$. It is also used for the treatment of acid-reflux disorders (GERD), peptic ulcer disease, active benign gastric ulcer and active

Address for Correspondence: V. Sravya, Department of Pharmaceutics, Browns College of Pharmacy, Khammam, Telangana, India; E-mail: sravya.vandanapu@gmail.com

How to Cite this Article: Sravya V, Suresh Kumar P, Jagannath Patro V, Sunitha Ch. Formulate gastroretentive floating bioadhesive drug delivery system of nizatidine by direct compression technique. World J Pharm Sci 2022; 10(01): 59-73; https://doi.org/10.54037/WJPS.2022.100106

Copyright:2022@ The Author(s). This is an open access article distributed under the terms of the Creative Commons AttributionNonCommercial-ShareAlike 4.0 International License (CC BY-NC-SA), which allows re-users to distribute, remix, adapt, and build upon the material in any medium or format for noncommercial purposes only, and only so long as attribution is given to the creator. If you remix, adapt, or build upon the material, you must license the modified material under identical terms. 
duodenal ulcers. It has a very short biological halflife 1-2 hours and low absolute oral bioavailability. It does not have any demonstrable anti-androgenic effects and drug interactions compared to any other class of $\mathrm{H}_{2}$ - receptor antagonists ${ }^{5}$. It also finds applications in the field of local delivery of drug to the stomach and proximal small intestine and importantly in treating microorganisms (Helicobacter pylori), which colonize the stomach because the major factors governing reduced luminal drug delivery are gastric acidity, gastric emptying and the epithelial mucus layer and therefore it helps to provide better availability of new products with new therapeutic possibilities and increased patient compliance ${ }^{6}$.

The aim of the present study is to design and evaluate the effervescent floating tablets of Nizatidine by using different polymers like Chitosan, HPMC and Carbopol940 and gas generating agents like sodium bicarbonate and calcium carbonate.

\section{MATERIALS AND METHODS}

Nizatidine was obtained as a gift sample from Dr. Reddy's laboratories, Hyderabad. HPMCK100M was purchased from SD Fine Chem. Ltd. Mumbai. Carbopol 940 was purchased from Loba chem. Mumbai. Chitosan was purchased from India Sea Food, Cochin. Lactose, Sodium bicarbonate, Calcium carbonate, magnesium stearate and talc are purchased from Qualigens fine chemicals, Mumbai. All excipients were analytical grade ${ }^{7,8}$.

Formulation of floating-bioadhesive tablets of Nizatidine:

Procedure for floating-bioadhesive tablet preparation: Sustained release bioadhesivefloating tablets were prepared by direct compression method. Accurately weighed quantities of hydrophilic polymers, bioadhesive polymer, microcrystalline cellulose were taken in a motar and required quantity of Nizatidine was added and mixed slightly with pestle. This mixture was passed through 40\# mesh and later collected in a plastic bag and blended for $5 \mathrm{~min}$. To this required amount of sodium bicarbonate was added and again mixed for $5 \mathrm{~min}$. Later $1 \%$ of magnesium stearate was added and final blend was again passed through 40\# mesh. Thus obtained blend was mixed thoroughly for $10 \mathrm{~min}$ and compressed into tablets $^{9,10}$.

Table.1: Composition of Nizatidine floating-bioadhesive tablets

\begin{tabular}{|l|l|l|l|l|l|l|l|l|}
\hline $\begin{array}{c}\text { Formula } \\
\text { code }\end{array}$ & Drug & $\begin{array}{l}\text { HPMC } \\
\text { K15M }\end{array}$ & $\begin{array}{l}\text { HPMC } \\
\text { K4M }\end{array}$ & $\begin{array}{l}\text { Carbopol } \\
934 \mathrm{P}\end{array}$ & $\begin{array}{l}\text { Sodium } \\
\text { CMC }\end{array}$ & $\begin{array}{l}\text { Sodium } \\
\text { alginate }\end{array}$ & NaHCO $_{3}$ & MCC \\
\hline F1 & 150 & - & 125 & 25 & - & - & 60 & 36 \\
\hline F2 & 150 & - & 120 & 30 & - & - & 60 & 36 \\
\hline F3 & 150 & - & 112.5 & 37.5 & - & - & 60 & 36 \\
\hline F4 & 150 & - & 125 & - & 25 & - & 60 & 36 \\
\hline F5 & 150 & - & 120 & - & 30 & - & 60 & 36 \\
\hline F6 & 150 & - & 112.5 & - & 37.5 & - & 60 & 36 \\
\hline F7 & 150 & & 125 & - & - & 25 & 60 & 36 \\
\hline F8 & 150 & & 120 & - & - & 30 & 60 & 36 \\
\hline F9 & 150 & & 112.5 & - & - & 37.5 & 60 & 36 \\
\hline F10 & 150 & 125 & - & 25 & - & - & 60 & 36 \\
\hline F11 & 150 & 120 & - & 30 & - & - & 60 & 36 \\
\hline F12 & 150 & 112.5 & - & 37.5 & - & - & 60 & 36 \\
\hline F13 & 150 & 125 & - & - & 25 & - & 60 & 36 \\
\hline F14 & 150 & 120 & - & - & 30 & - & 60 & 36 \\
\hline F15 & 150 & 112.5 & - & - & 37.5 & - & 60 & 36 \\
\hline F16 & 150 & 125 & - & - & - & 25 & 60 & 36 \\
\hline F17 & 150 & 120 & - & - & - & 30 & 60 & 36 \\
\hline F18 & 150 & 112.5 & - & - & - & 37.5 & 60 & 36 \\
\hline All th
\end{tabular}

All the ingredients are in $\mathrm{mg}$ and total weight of each tablet is $400 \mathrm{mg}$.

Evaluation parameters ${ }^{11-15}$ :

Precompression parameters:

Angle of Repose: Angle of repose has been defined as the maximum angle possible between the surfaces of pile of powder and horizontal plane. It is performed to determine the flow rate of powder done by the funnel method. The powder mass was allowed to flow through the funnel orifice kept vertically to a plane paper kept on the horizontal surface, giving a heap angle of powder on paper. The angle of repose was calculated by substituting the values of the base radius ' $r$ ' and pile height ' $h$ ' in the following equation: 
Bulk Density: It is the ratio of total mass of powder to the bulk volume of powder. It was measured by pouring the weight powder (passed through standard sieve \# 20) into a measuring cylinder and initial weight was noted. This initial volume is called the bulk volume. From this the bulk density is calculated according to the formula mentioned below. It is expressed in $\mathrm{g} / \mathrm{ml}$ and is given by,

Tapped density: It is the ratio of total mass of the powder to the tapped volume of the powder. Volume was measured by tapping the powder for 750 times if the difference between these two volumes is less than $2 \%$. If it is more than $2 \%$, tapping was continued for 1250 times and tapped volume was noted. Tapping was continued until the difference between successive volumes is less than $2 \%$ (in a bulk density apparatus). It is expressed in $\mathrm{g} / \mathrm{ml}$ and is given by

Carr's index: Carr developed an indirect method of measuring powder flow from densities. The percentage compressibility of a powder was a direct measure of the potential powder arch or bridge strength and stability. Carr's index of each formulation was calculated by

Hausner's ratio: Hausner Ratio is the measure of the propensity of a powder to be compressed. As such, they are measures of the relative importance of inter particulate interactions. In a free-flowing powder, such interactions are generally less significant, and the bulk and tapped densities will be closer in value. For poorer flowing materials, there are frequently greater interparticle interactions and a greater difference between the bulk and tapped densities will be observed. These differences are reflected in the Hausner Ratio, which are calculated using the following formulae:

\section{Post compression parameters:}

Weight variation: To study weight variation individual weights $\left(\mathrm{W}_{\mathrm{I}}\right)$ of 20 tablets from each formulation were weighed using electronic balance. Their average weight $\left(\mathrm{W}_{\mathrm{A}}\right)$ was calculated. Percent weight variation was calculated as follows. Average weights of the tablets along with standard deviation values were calculated.

Tablet hardness: Tablet hardness was measured using a Monsanto hardness tester. The crushing strength of the 3 tablets with known weight and thickness of each was recorded in $\mathrm{kg} / \mathrm{cm}^{2}$ and the average hardness and standard deviation were calculated.

Tablet thickness: The thickness of tablets was determined by using vernier calipers. Three tablets from each batch were used, average thickness and standard deviation were calculated.

Friability: From each batch, 3 tablets were accurately weighed. Each group of tablets was rotated in the Friability test apparatus (Roche friabilator) at $25 \mathrm{rpm}$ for 4 minutes (100 rotations). The tablets were then dedusted and reweighed to determine the loss in weight. The friability was calculated as the percent weight loss from actual weight of tablets.

Content uniformity: The formulated Nizatidine floating-bioadhesive tablets were assayed for drug content.

Buoyancy / Floating Test: The in vitro buoyancy was determined by floating lag time, as per the method described by a Rosa et al., 1994. Here, the tablets were placed in a $100-\mathrm{mL}$ beaker containing $0.1 \mathrm{~N} \mathrm{HCl}$. The time required for the tablet to rise to the surface and to float was determined as floating lag time and total duration of time by which dosage form remain buoyant is called Total Floating Time (TFT).

Swelling characteristics: The swelling properties of matrices containing drug were determined by placing the tablet matrices in the dissolution test apparatus, in $900 \mathrm{ml} 0.1 \mathrm{~N} \mathrm{HCl}$ at $37 \pm 0.5^{\circ} \mathrm{C}$. The tablets were removed periodically from the dissolution medium and, after removing free water, the weight gain was measured.

Bioadhesive strength: Mucoadhesive strength of the tablet was measured on the modified physical balance. The design used for measuring the mucoadhesive strength. The apparatus consist of a modified double beam physical balance in which the right pan has been replaced by a glass slide with copper wire and additional weight, to make the right side weight equal with left side pan. A taflone block of $3.8 \mathrm{~cm}$ diameter and $2 \mathrm{~cm}$ height was fabricated with an upward portion of $2 \mathrm{~cm}$ height and $1.5 \mathrm{~cm}$ diameter on one side. This was kept in beaker filled with buffer media $0.1 \mathrm{~N} \mathrm{HCl}$ $\mathrm{pH} 1.2$, which was then placed below right side of the balance.

\section{In-vitro Drug Release : Procedure}

The in-vitro dissolution studies were performed for the formulated floating-bioadhesive tablets of nizatidine over a period of 12 hours, using USP dissolution test apparatus 2 (paddle method) at 50 rpm, [Electro lab, TDT - 082].A minimum of 3 tablets per each batch was tested. The dissolution medium consists of $900 \mathrm{ml}$ of $0.1 \mathrm{~N} \mathrm{HCl}$ and temperature was maintained at $37 \pm 0.5{ }^{\circ} \mathrm{C}$. The tablets were placed inside the dissolution vessel. 
An aliquot $(5 \mathrm{ml})$ of sample was withdrawn at specific time intervals of $30,60,120,180,240$, 300, 360, 420, 480, 540, 600, 660 and 720 minutes. The volume of dissolution fluid adjusted to by replacing $5 \mathrm{ml}$ of dissolution medium after each sampling. Each sample was analyzed at $315 \mathrm{~nm}$ using double beam UV and Visible Spectrophotometer against reagent blank.

\section{Kinetic Analysis of Dissolution Data:}

To analyze the in-vitro release data various kinetic models were used to describe the release kinetics. The zero order rate Eq. (1) describes the systems where the drug release rate is independent of its concentration (Hadjiioannou et al., 1993). The first order Eq. (2) describes the release from system where release rate is concentration dependent (Bourne, 2002). Higuchi (1963) described the release of drugs from insoluble matrix as a square root of time dependent process based on Fickian diffusion Eq. (3). The Hixson-Crowell cube root law Eq. (4) describes the release from systems where there is a change in surface area and diameter of particles or tablets (Hixson and Crowell, 1931).

\section{RESULTS \& DISCUSSION}

Drug-excipient Compatibility studies:

Fourier Transform Infrared spectroscopic studies (FT-IR):

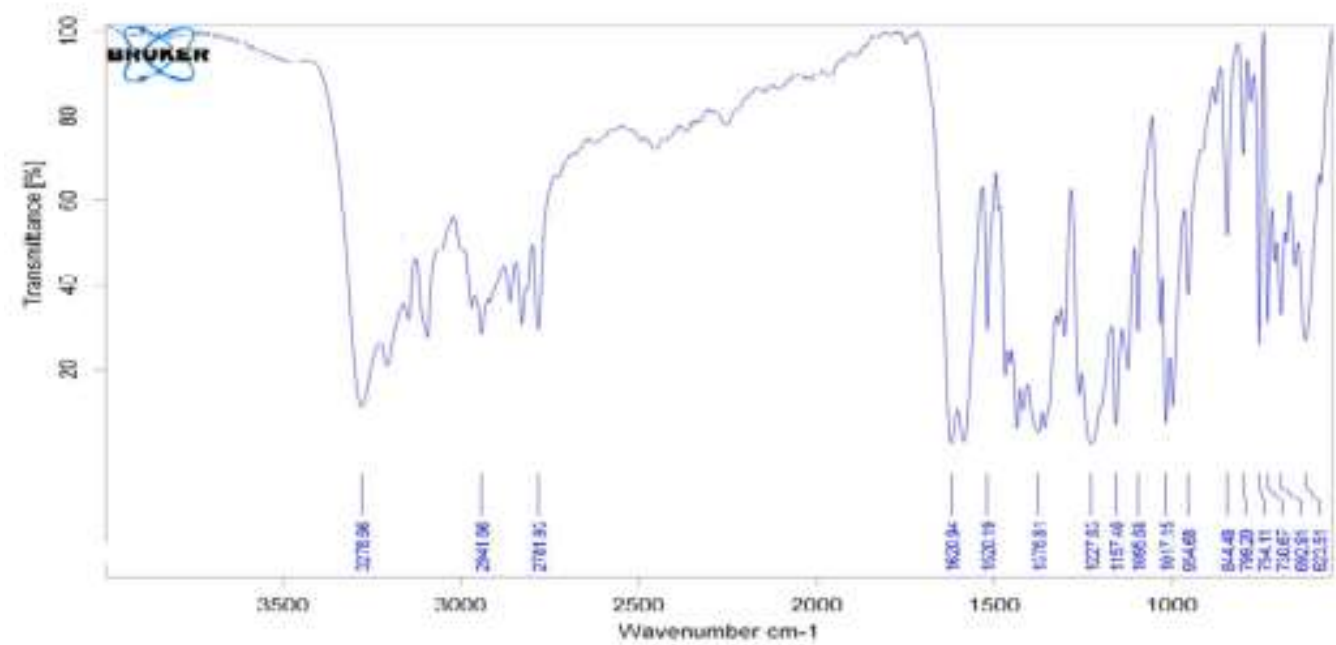

Figure 1. FT-IR spectrum of Nizatidine pure drug

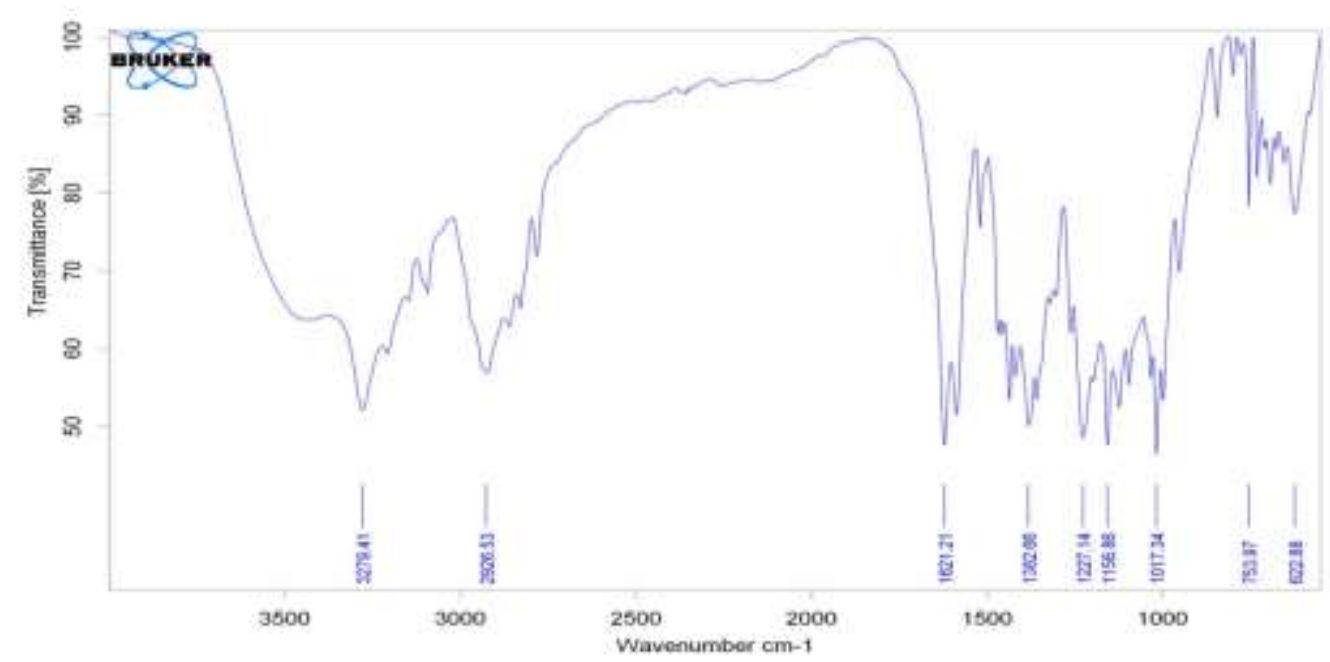

Figure 2: FT-IR spectrum of Nizatidine + HPMC K4M+ Sodium CMC 


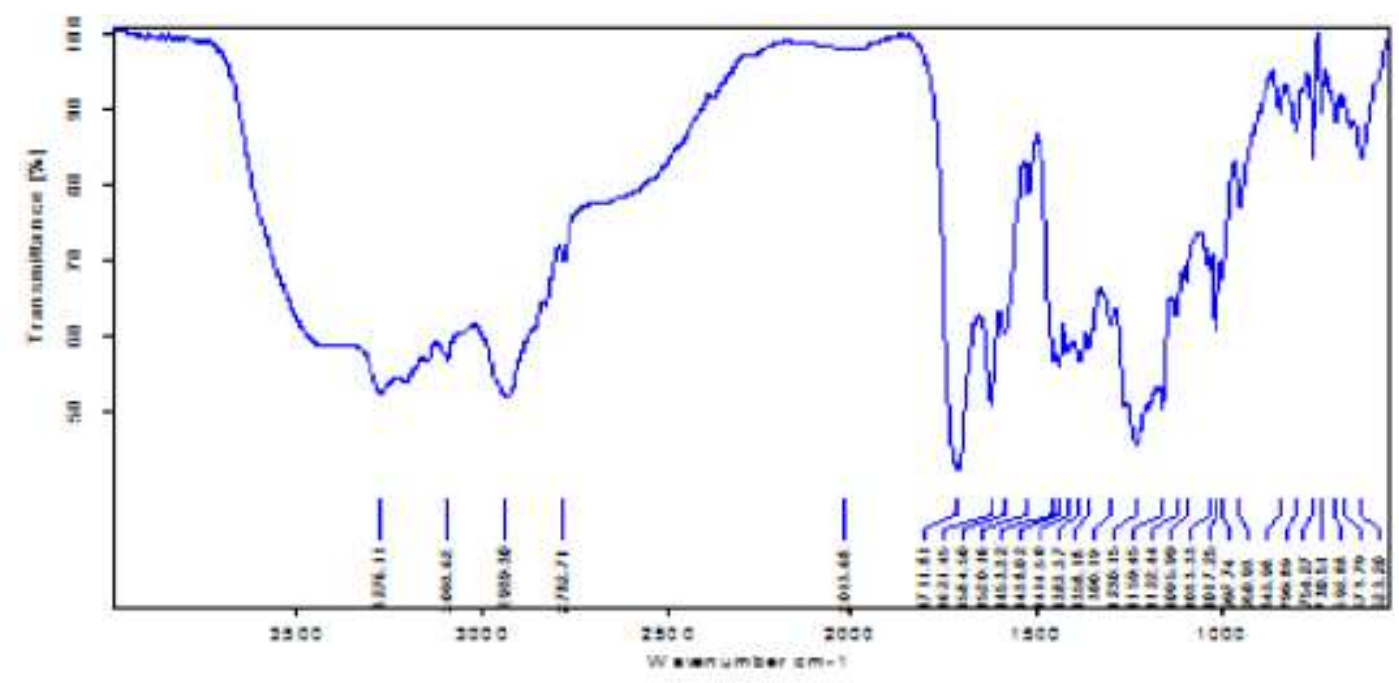

Figure 3: FT-IR spectrum of Nizatidine + HPMC K4M +Carbopol 934P

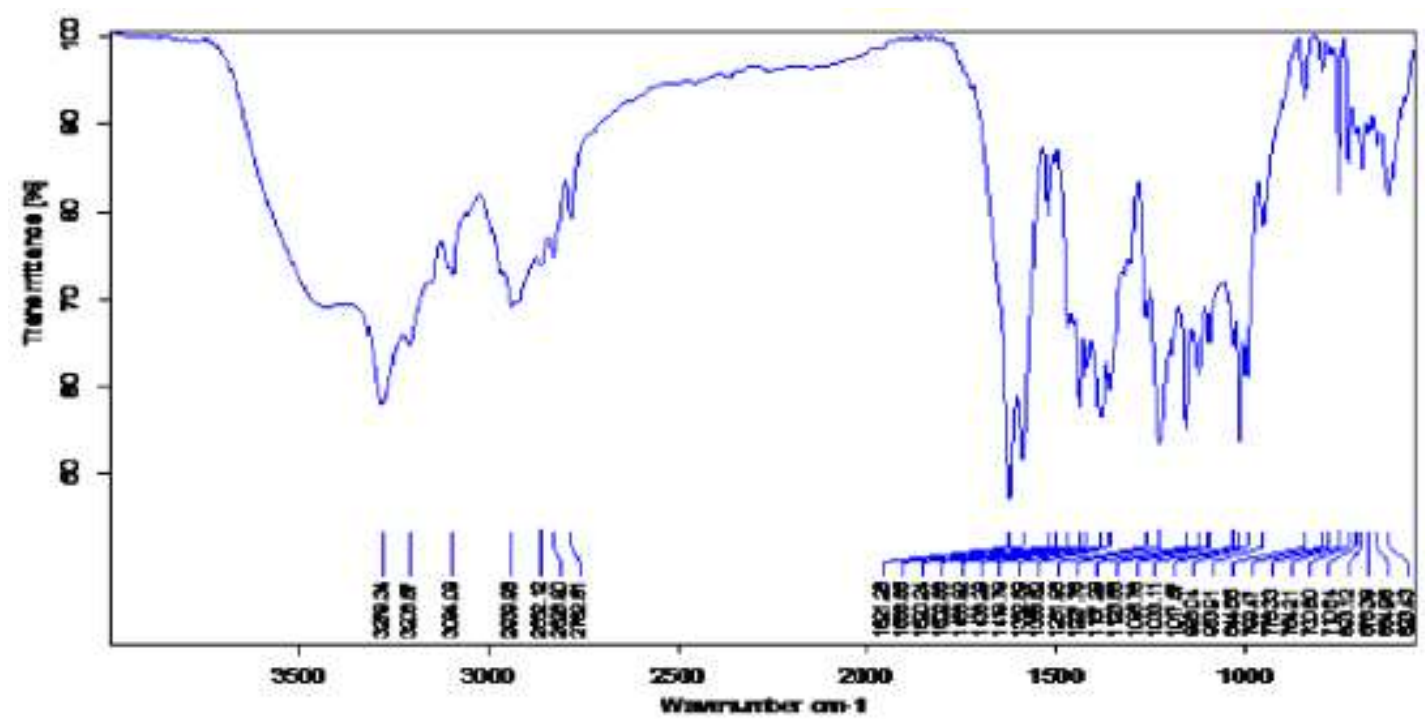

Figure 4: FT-IR spectrum of Nizatidine+ HPMCK4M+ Sodium alginate

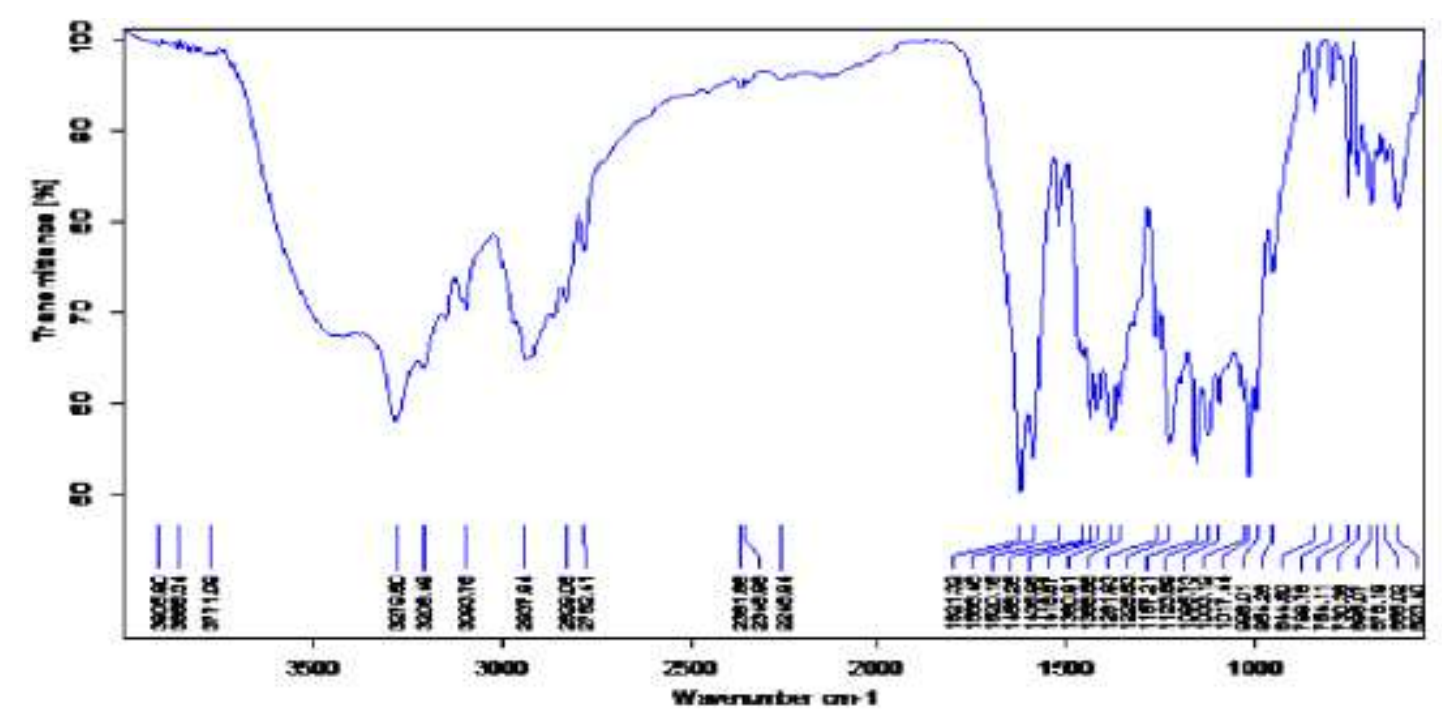

Figure 5: FT-IR spectrum of Nizatidine + HPMCK15M +Sodium CMC 


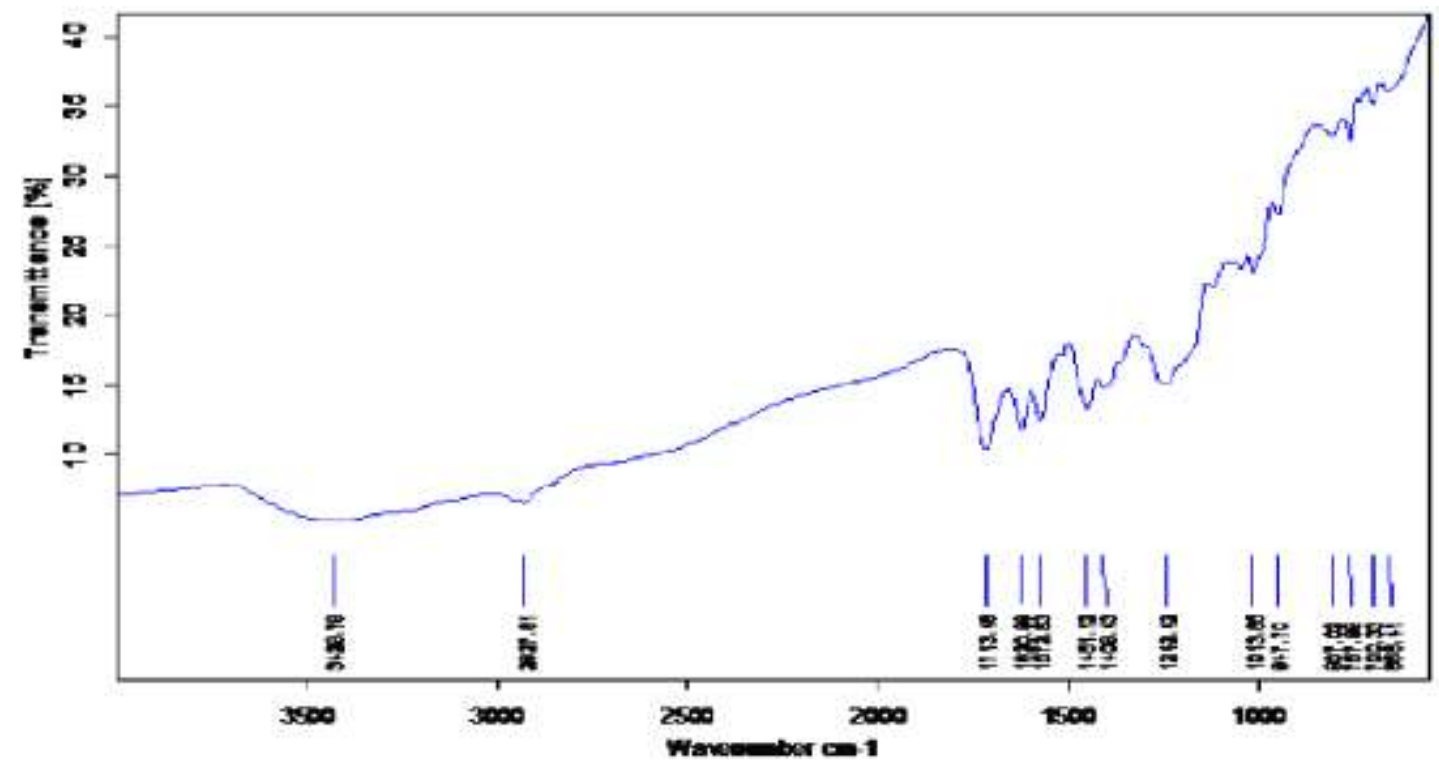

Figure 6: FT-IR spectrum of Nizatidine + HPMC K15M+ Carbopol 934P

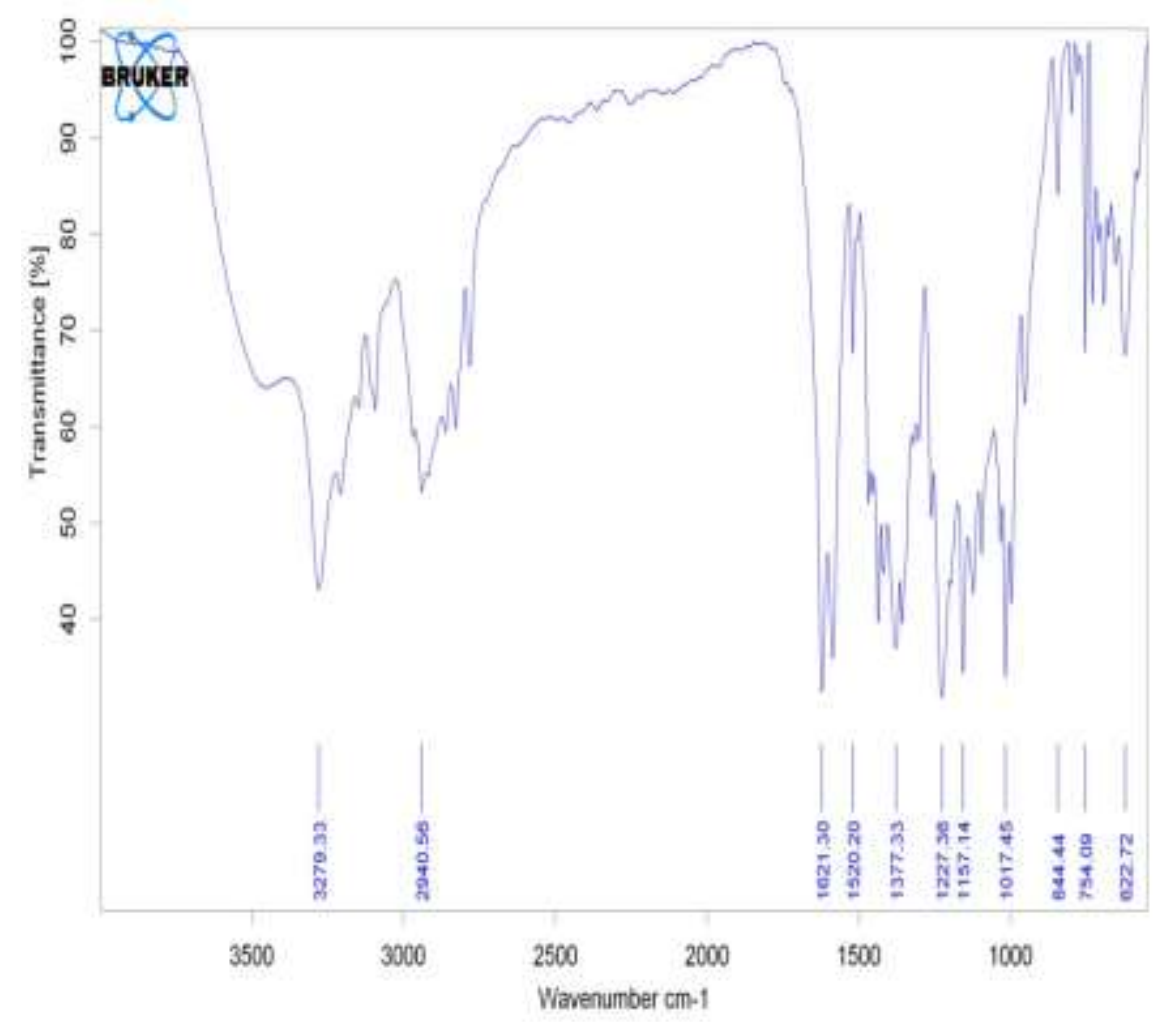

Figure 7: FT-IR spectrum of Nizatidine + HPMC K15M+ Sodium alginate

Thermographs obtained by DSC studies, revealed that the melting point of pure drug is $136.8^{\circ} \mathrm{C}$ and that formulation F12 shows sharp endothermic peak at $136{ }^{\circ} \mathrm{C}$ as there is no much difference in melting point of the drug in the thermographs and that of in the formulation. It may be concluded that, the drug is in the formulation without interacting with the polymer and excipients. 
Precompression parameters:

Table 2: Precompression parameters of tablets using powder blend

\begin{tabular}{|c|c|c|c|c|c|}
\hline $\begin{array}{l}\text { Formulation } \\
\text { Code }\end{array}$ & $\begin{array}{l}\text { Bulk } \\
\text { Density (g/ml) }\end{array}$ & $\begin{array}{l}\text { Tapped } \\
\text { Density } \\
(\mathrm{g} / \mathrm{ml})\end{array}$ & $\begin{array}{l}\text { Angle of } \\
\text { Repose } \\
(\circ)\end{array}$ & $\begin{array}{l}\text { Compressibility } \\
\text { Index }(\%)\end{array}$ & $\begin{array}{l}\text { Hausner's } \\
\text { ratio }\end{array}$ \\
\hline F1 & $0.434 \pm 0.001$ & $0.519 \pm 0.001$ & $26.5 \pm 0.5$ & 16.3 & 1.19 \\
\hline F2 & $0.487 \pm 0.002$ & $0.563 \pm 0.003$ & $27.4 \pm 0.8$ & 13.4 & 1.15 \\
\hline F3 & $0.426 \pm 0.003$ & $0.489 \pm 0.002$ & $25.1 \pm 0.2$ & 12.8 & 1.14 \\
\hline F4 & $0.506 \pm 0.004$ & $0.597 \pm 0.001$ & $28.3 \pm 0.2$ & 15.2 & 1.17 \\
\hline F5 & $0.500 \pm 0.003$ & $0.579 \pm 0.002$ & $28.3 \pm 0.1$ & 13.6 & 1.15 \\
\hline F6 & $0.510 \pm 0.008$ & $0.592 \pm 0.007$ & $27.9 \pm 0.8$ & 13.8 & 1.16 \\
\hline F7 & $0.500 \pm 0.001$ & $0.579 \pm 0.002$ & $29.2 \pm 0.5$ & 13.6 & 1.15 \\
\hline F8 & $0.487 \pm 0.002$ & $0.555 \pm 0.004$ & $26.5 \pm 0.5$ & 12.2 & 1.13 \\
\hline F9 & $0.484 \pm 0.005$ & $0.568 \pm 0.006$ & $27.2 \pm 0.2$ & 14.7 & 1.17 \\
\hline F10 & $0.487 \pm 0.002$ & $0.563 \pm 0.002$ & $27.9 \pm 0.4$ & 13.4 & 1.15 \\
\hline F11 & $0.502 \pm 0.002$ & $0.576 \pm 0.003$ & $25.1 \pm 0.2$ & 12.8 & 1.14 \\
\hline F12 & $0.487 \pm 0.004$ & $0.563 \pm 0.006$ & $27.4 \pm 0.3$ & 13.4 & 1.15 \\
\hline F13 & $0.500 \pm 0.001$ & $0.579 \pm 0.003$ & $28.3 \pm 0.4$ & 13.6 & 1.15 \\
\hline F14 & $0.504 \pm 0.002$ & $0.582 \pm 0.003$ & $25.6 \pm 0.2$ & 13.4 & 1.15 \\
\hline F15 & $0.512 \pm 0.001$ & $0.596 \pm 0.006$ & $25.1 \pm 0.8$ & 14.0 & 1.16 \\
\hline F16 & $0.487 \pm 0.002$ & $0.555 \pm 0.003$ & $26.5 \pm 0.1$ & 12.2 & 1.13 \\
\hline F17 & $0.489 \pm 0.001$ & $0.562 \pm 0.006$ & $28.3 \pm 0.1$ & 12.9 & 1.14 \\
\hline F18 & $0.503 \pm 0.002$ & $0.586 \pm 0.003$ & $27.4 \pm 0.3$ & 14.1 & 1.16 \\
\hline
\end{tabular}

Values are mean $\pm \mathrm{SD}, \mathrm{n}=3$

The data's were shown in table. The values for angle of repose were found in the range of $25^{\circ}-30^{\circ}$. Bulk densities and tapped densities of various formulations were found to be in the range of 0.426 \pm 0.003 to $0.510 \pm 0.008(\mathrm{gm} / \mathrm{ml})$ and $0.489+0.002$ to $0.596 \pm 0.006(\mathrm{gm} / \mathrm{ml})$ respectively. Carr's index of the prepared blends fall in the range of $12.2 \%$ to $16 \%$. The Hausner ration fall in range of 1.13 to 1.19. From the result it was concluded that the powder blends had good flow properties and these can be used for tablet manufacture.

\section{Post compression parameters:}

Table 3: Post compression parameters

\begin{tabular}{|l|l|l|l|l|l|}
\hline $\begin{array}{c}\text { Formulation } \\
\text { Code }\end{array}$ & $\begin{array}{l}\text { Weight } \\
\text { Variation(mg) }\end{array}$ & $\begin{array}{l}\text { Hardness } \\
\left(\mathbf{k g} / \mathbf{c m}^{\mathbf{2}}\right)\end{array}$ & $\begin{array}{l}\text { Thickness } \\
(\mathbf{~ m m})\end{array}$ & $\begin{array}{l}\text { Friability } \\
(\mathbf{\%})\end{array}$ & Assay $(\boldsymbol{\%})$ \\
\hline F1 & $401 \pm 0.4$ & $6.1 \pm 0.1$ & $4.11 \pm 0.01$ & $0.3 \pm 0.01$ & $97.23 \pm 0.510$ \\
\hline F2 & $399 \pm 0.5$ & $6.5 \pm 0.1$ & $4.22 \pm 0.02$ & $0.4 \pm 0.02$ & $98.55 \pm 0.470$ \\
\hline F3 & $398 \pm 0.6$ & $6.0 \pm 0.3$ & $4.10 \pm 0.03$ & $0.4 \pm 0.02$ & $98.16 \pm 0.330$ \\
\hline F4 & $401 \pm 0.2$ & $5.4 \pm 0.1$ & $4.14 \pm 0.01$ & $0.2 \pm 0.01$ & $99.34 \pm 0.420$ \\
\hline F5 & $400 \pm 0.3$ & $5.7 \pm 0.2$ & $4.13 \pm 0.01$ & $0.5 \pm 0.02$ & $98.16 \pm 0.330$ \\
\hline F6 & $399 \pm 0.1$ & $5.1 \pm 0.3$ & $4.11 \pm 0.04$ & $0.2 \pm 0.01$ & $98.55 \pm 0.470$ \\
\hline F7 & $398 \pm 0.7$ & $5.8 \pm 0.1$ & $4.20 \pm 0.01$ & $0.3 \pm 0.01$ & $98.16 \pm 0.330$ \\
\hline F8 & $400 \pm 0.4$ & $5.6 \pm 0.2$ & $4.18 \pm 0.01$ & $0.6 \pm 0.01$ & $99.25 \pm 0.670$ \\
\hline F9 & $399 \pm 0.3$ & $5.7 \pm 0.1$ & $4.17 \pm 0.02$ & $0.3 \pm 0.01$ & $99.25 \pm 0.670$ \\
\hline F10 & $398 \pm 0.2$ & $6.8 \pm 0.4$ & $4.21 \pm 0.01$ & $0.4 \pm 0.02$ & $97.12 \pm 0.280$ \\
\hline F11 & $399 \pm 0.3$ & $6.5 \pm 0.2$ & $4.20 \pm 0.01$ & $0.2 \pm 0.01$ & $98.56 \pm 0.760$ \\
\hline F12 & $400 \pm 0.4$ & $6.9 \pm 0.1$ & $4.11 \pm 0.01$ & $0.3 \pm 0.02$ & $99.34 \pm 0.420$ \\
\hline F13 & $399 \pm 0.5$ & $5.6 \pm 0.2$ & $4.13 \pm 0.04$ & $0.5 \pm 0.01$ & $98.16 \pm 0.330$ \\
\hline
\end{tabular}


Sravya et al., World J Pharm Sci 2022; 10(01): 59-73

\begin{tabular}{|l|l|l|l|c|l|}
\hline F14 & $402 \pm 0.3$ & $5.2 \pm 0.3$ & $4.10 \pm 0.03$ & $0.6 \pm 0.01$ & $101.5 \pm 0.470$ \\
\hline F15 & $399 \pm 0.2$ & $5.0 \pm 0.1$ & $4.17 \pm 0.02$ & $0.4 \pm 0.02$ & $98.16 \pm 0.330$ \\
\hline F16 & $397 \pm 0.3$ & $5.7 \pm 0.2$ & $4.16 \pm 0.01$ & $0.3 \pm 0.01$ & $99.25 \pm 0.670$ \\
\hline F17 & $398 \pm 0.4$ & $5.9 \pm 0.3$ & $4.19 \pm 0.02$ & $0.5 \pm 0.01$ & $102.5 \pm 0.670$ \\
\hline F18 & $400 \pm 0.4$ & $5.8 \pm 0.1$ & $4.18 \pm 0.01$ & $0.2 \pm 0.02$ & $97.12 \pm 0.280$ \\
\hline
\end{tabular}

Values are mean \pm SD $n=3$

Results revealed that all the formulated tablets were of good quality with regard to hardness $((5 \pm 0.1$ $\left.6.9 \pm 0.1 \mathrm{~kg} / \mathrm{cm}^{2}\right)$, thickness $(4.1 \pm 0.01-4.2 \pm$
$0.01 \mathrm{~mm})$, weight variation $(397 \pm 0.3-402 \pm$ $0.3 \mathrm{mg})$ and drug content $(97.1 \pm 0.2-102.5 \pm 0.6$ $\%)$.

\section{Floating properties}

Table 4: Floating properties of all formulations

\begin{tabular}{|c|c|c|}
\hline $\begin{array}{c}\text { Formulation } \\
\text { code }\end{array}$ & Floating lag time(sec) & Floating duration( hrs) \\
\hline F1 & $70 \pm 2.8$ & $>12$ \\
\hline F2 & $76 \pm 2.0$ & $>12$ \\
\hline F3 & $84 \pm 2.1$ & $>12$ \\
\hline F4 & $79 \pm 2.3$ & $>12$ \\
\hline F5 & $86 \pm 3.4$ & $>12$ \\
\hline F6 & $95 \pm 2.0$ & $>12$ \\
\hline F7 & $72 \pm 2.5$ & $>12$ \\
\hline F8 & $85 \pm 4.0$ & $>12$ \\
\hline F9 & $87 \pm 1.5$ & $>12$ \\
\hline F10 & $78 \pm 4.6$ & $>12$ \\
\hline F11 & $90 \pm 2.0$ & $>12$ \\
\hline F12 & $92 \pm 2.6$ & $>12$ \\
\hline F13 & $139 \pm 3.0$ & $>12$ \\
\hline F14 & $143 \pm 2.5$ & $>12$ \\
\hline F15 & $160 \pm 3.5$ & $>12$ \\
\hline F16 & $78 \pm 2.5$ & $>12$ \\
\hline F17 & $104 \pm 4.1$ & $>12$ \\
\hline F18 & $125 \pm 2.6$ & $>12$ \\
\hline
\end{tabular}

\section{Values are mean $\underline{+}$ SD $n=3$}

All tablet formulations exhibited satisfactory floatation ability and remained buoyant for more than $12 \mathrm{~h}$ in dissolution medium subjected to rotation. The floating lag time for all the formulations was found to be less than five minutes. From the results it was clearly observed that the reduction in concentration of HPMC in each batch resulted in increased floating lag time.

\section{Swelling characteristics:}

Table 5: Swelling index of all formulations

\begin{tabular}{|c|c|c|l|l|l|l|}
\hline \multirow{2}{*}{$\begin{array}{c}\text { Formulation } \\
\text { Code }\end{array}$} & \multicolumn{7}{|c|}{ Time (hrs) } \\
\cline { 2 - 7 } & $\mathbf{2}$ & $\mathbf{4}$ & $\mathbf{6}$ & $\mathbf{8}$ & $\mathbf{1 0}$ & $\mathbf{1 2}$ \\
\cline { 2 - 7 } & $45 \pm 0.9$ & $100 \pm 0.5$ & $107.5 \pm 0.1$ & $125 \pm 0.7$ & $77.5 \pm 0.6$ & $72.5 \pm 0.5$ \\
\hline F1 & $45 \pm 0.1$ & $97.5 \pm 0.3$ & $110 \pm 0.6$ & $125 \pm 0.7$ & $87.5 \pm 0.4$ & $70 \pm 0.6$ \\
\hline F2 & $50 \pm 0.6$ & $102.5 \pm 0.5$ & $115 \pm 0.4$ & $127.5 \pm 0.4$ & $90 \pm 0.8$ & $72.5 \pm 0.4$ \\
\hline F3 & $22.5 \pm 0.5$ & $30 \pm 0.4$ & $40 \pm 0.2$ & $30 \pm 0.8$ & $27.5 \pm 0.3$ & $22.5 \pm 0.5$ \\
\hline F5 & $27.5 \pm 0.3$ & $32.5 \pm 0.3$ & $42.5 \pm 0.5$ & $35 \pm 0.1$ & $25 \pm 0.9$ & $15 \pm 0.1$ \\
\hline F6 & $30 \pm 0.4$ & $37.5 \pm 0.3$ & $42.5 \pm 0.3$ & $40 \pm 0.8$ & $27.5 \pm 0.3$ & $17.5 \pm 0.4$ \\
\hline F7 & $30 \pm 0.8$ & $52.5 \pm 0.5$ & $50 \pm 0.6$ & $45 \pm 0.9$ & $42.5 \pm 0.5$ & $25 \pm 0.9$ \\
\hline F8 & $37.5 \pm 0.3$ & $55 \pm 0.9$ & $52.5 \pm 0.5$ & $47.5 \pm 0.4$ & $37.5 \pm 0.3$ & $27.5 \pm 0.4$ \\
\hline F9 & $40 \pm 0.2$ & $60 \pm 0.8$ & $55 \pm 0.9$ & $52.5 \pm 0.5$ & $40 \pm 0.2$ & $30 \pm 0.8$ \\
\hline F10 & $70 \pm 0.6$ & $102.5 \pm 0.5$ & $125 \pm 0.7$ & $172.5 \pm 0.5$ & $195 \pm 0.7$ & $190 \pm 0.8$ \\
\hline F12 & $77.5 \pm 0.3$ & $107.5 \pm 0.4$ & $127.5 \pm 0.4$ & $175 \pm 0.7$ & $210 \pm 0.8$ & $197.5 \pm 0.4$ \\
\hline
\end{tabular}


Sravya et al., World J Pharm Sci 2022; 10(01): 59-73

\begin{tabular}{|l|l|l|l|l|l|l|}
\hline F13 & $52.5 \pm 0.4$ & $100 \pm 0.6$ & $125 \pm 0.7$ & $147.5 \pm 0.3$ & $162.5 \pm 0.4$ & $162.5 \pm 0.4$ \\
\hline F14 & $57.5 \pm 0.4$ & $105 \pm 0.7$ & $130 \pm 0.6$ & $152.5 \pm 0.4$ & $172.5 \pm 0.5$ & $170 \pm 0.6$ \\
\hline F15 & $62.5 \pm 0.5$ & $105 \pm 0.7$ & $132.5+0.5$ & $157.5 \pm 0.3$ & $180 \pm 0.8$ & $177.5 \pm 0.4$ \\
\hline F16 & $55 \pm 0.9$ & $80 \pm 0.8$ & $130 \pm 0.4$ & $160 \pm 0.8$ & $167.5 \pm 0.4$ & $165 \pm 0.9$ \\
\hline F17 & $57.5 \pm 0.4$ & $85 \pm 0.9$ & $130 \pm 0.8$ & $165 \pm 0.9$ & $185 \pm 0.1$ & $182.5 \pm 0.4$ \\
\hline F18 & $60 \pm 0.8$ & $97.5 \pm 0.3$ & $132.5 \pm 0.5$ & $182.5 \pm 0.5$ & $200 \pm 0.8$ & $202.5 \pm 0.5$ \\
\hline
\end{tabular}

Values are mean \pm SD $n=3$

The swelling index of all formulations was found to be ranging in between $22.5 \pm 0.5 \%$ to $217.5 \pm 0.4$ $\%$. All formulations containing HPMC K4M and HPMC K15M have exhibited good swelling and tablet integrity. Swelling is also a vital factor to ensure buoyancy and drug dissolution of the tablet. As reported by Bertram and Bodmeier, the ability of hydrogels to absorb water is due to the presence of hydrophilic groups. The hydration of these functional groups results in water entry into the polymer chains. It was observed that the swelling index of the tablets increases with an increase in the polymer viscosity grades.

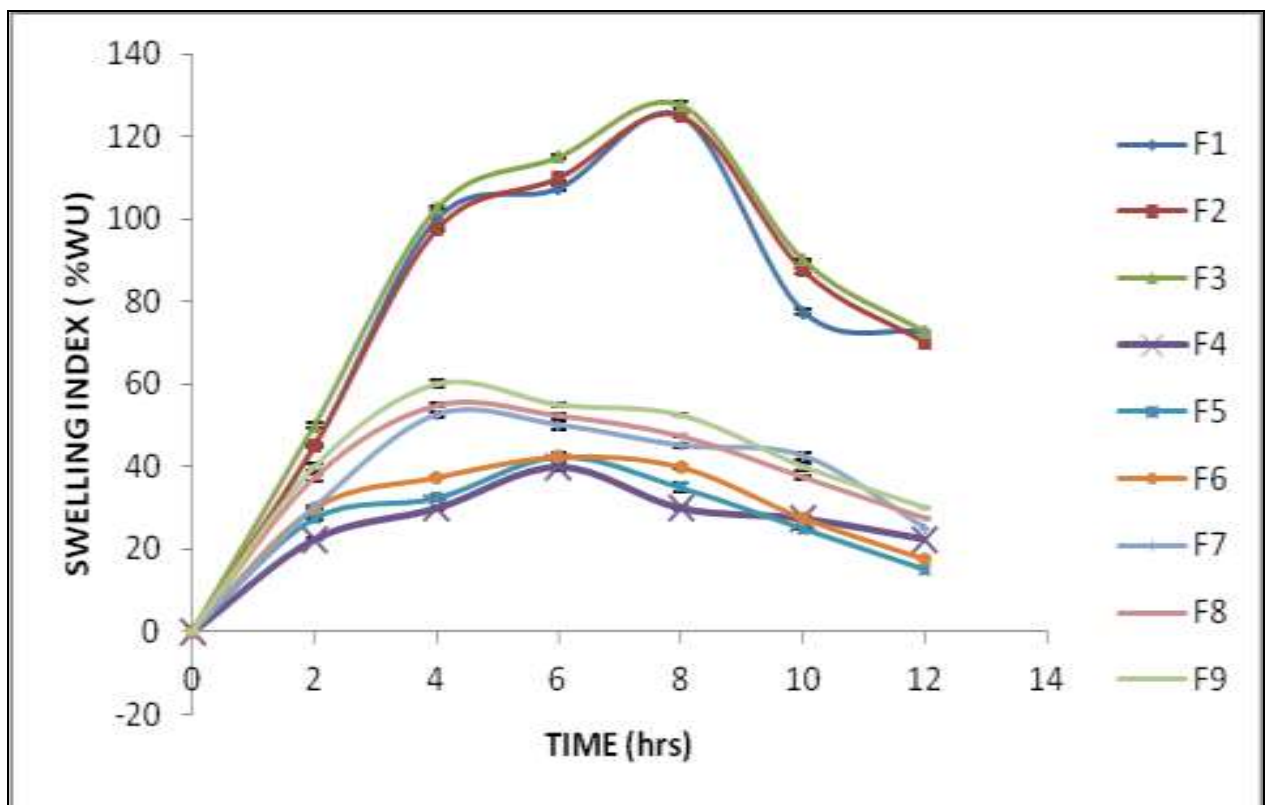

Figure 8: Swelling index of formulations F1 to F9

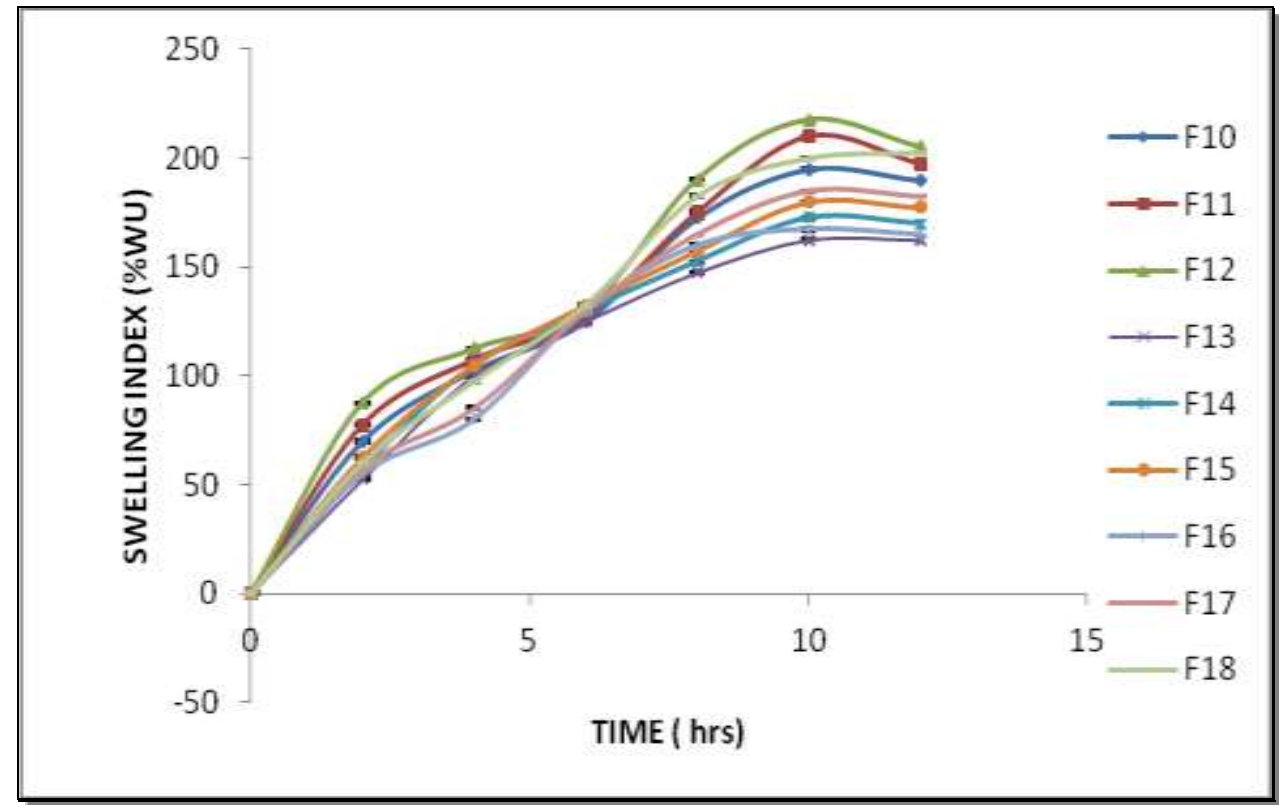

Figure 9: Swelling index of formulations F10 to F18 
Bioadhesive strength:

Table 6: Bioadhesive strength of all formulations

\begin{tabular}{|c|c|}
\hline Formulation code & Bioadhesive strength (gm) \\
\hline F1 & $17 \pm 0.8$ \\
\hline F2 & $20 \pm 0.5$ \\
\hline F3 & $22 \pm 0.7$ \\
\hline F5 & $15 \pm 0.2$ \\
\hline F6 & $17 \pm 0.2$ \\
\hline F7 & $19 \pm 0.7$ \\
\hline F8 & $16 \pm 0.6$ \\
\hline F9 & $19 \pm 0.1$ \\
\hline F10 & $21 \pm 0.2$ \\
\hline F11 & $23 \pm 0.8$ \\
\hline F12 & $25 \pm 0.2$ \\
\hline F13 & $29 \pm 0.4$ \\
\hline F14 & $20 \pm 0.6$ \\
\hline F16 & $23 \pm 0.5$ \\
\hline F17 & $25 \pm 0.7$ \\
\hline F18 & $22 \pm 0.8$ \\
\hline
\end{tabular}

Values are mean \pm SD $n=3$

All formulations showed bioadhesive strength in the range of $15 \pm 0.2$ to $29 \pm 0.4 \mathrm{~g}$. Bioadhesive strength depends on the viscosity and concentration of the polymer. Formulations F1 to F9 have shown low bioadhesion strength due to the lower viscosity of HPMC K4M. While formulations F10 to F18 containing HPMC K15M have shown higher bioadhesion strength due to higher viscosity. It was found that as the concentration of the bioadhesive polymer increases the bioadhesion strength also increases.

In-vitro drug release:

Table 7: Cumulative \% drug release of formulations F1 to F6

\begin{tabular}{|c|c|c|l|l|l|l|}
\hline \multirow{2}{*}{$\begin{array}{c}\text { TIME } \\
(\mathbf{h r s})\end{array}$} & \multicolumn{7}{|c|}{ FORMULATON CODE } \\
\cline { 2 - 7 } & $\mathbf{F 1}$ & F2 & F3 & F4 & F5 & F6 \\
\cline { 2 - 7 } & $16.5 \pm 0.1$ & $16 \pm 0.2$ & $15.7 \pm 0.4$ & $19 \pm 0.3$ & $18.7 \pm 0.2$ & $16 \pm 0.1$ \\
\hline $\mathbf{0 . 5}$ & $22.8 \pm 0.2$ & $21.3 \pm 0.3$ & $20 \pm 0.05$ & $25.1 \pm 0.3$ & $24.6 \pm 0.1$ & $24.8 \pm 0.3$ \\
\hline $\mathbf{2}$ & $30.7 \pm 0.7$ & $30.2 \pm 0.4$ & $30.4 \pm 0.1$ & $32.7 \pm 0.2$ & $33.9 \pm 0.5$ & $33.9 \pm 0.3$ \\
\hline $\mathbf{3}$ & $42.6 \pm 0.3$ & $40.3 \pm 0.2$ & $41.3 \pm 0.1$ & $48.6 \pm 0.7$ & $45.6 \pm 0.3$ & $45.1 \pm 0.4$ \\
\hline $\mathbf{4}$ & $53.1 \pm 0.5$ & $53.3 \pm 0.5$ & $52.8 \pm 0.4$ & $61.4 \pm 0.2$ & $60.4 \pm 0.5$ & $61.1 \pm 0.3$ \\
\hline $\mathbf{5}$ & $51.9 \pm 0.1$ & $58.8 \pm 0.6$ & $58.6 \pm 0.3$ & $73.2 \pm 0.7$ & $68.7 \pm 0.4$ & $68.2 \pm 0.4$ \\
\hline $\mathbf{6}$ & $71.2 \pm 0.2$ & $69.2 \pm 0.4$ & $68.7 \pm 0.5$ & $87.4 \pm 0.5$ & $80.1 \pm 0.5$ & $80.3 \pm 0.5$ \\
\hline $\mathbf{7}$ & $80.1 \pm 0.2$ & $79 \pm 0.3$ & $78.8 \pm 0.4$ & $99.4 \pm 0.2$ & $93.5 \pm 0.1$ & $95.8 \pm 0.4$ \\
\hline $\mathbf{8}$ & $92 \pm 0.2$ & $90.7 \pm 0.4$ & $89.7 \pm 0.2$ & $108.9 \pm 0.6$ & $107 \pm 0.2$ & $106 \pm 0.2$ \\
\hline $\mathbf{9}$ & $102.3 \pm 0.3$ & $101.5 \pm 0.5$ & $101 \pm 0.5$ & - & - & - \\
\hline $\mathbf{1 0}$ & - & - & - & - & - & - \\
\hline $\mathbf{1 1}$ & - & - & - & - & - & - \\
\hline $\mathbf{1 2}$ & - & - & - & - & - & - \\
\hline
\end{tabular}


Table 8: Cumulative \% drug release of formulations F7 to F12

\begin{tabular}{|c|c|c|c|l|l|l|}
\hline \multirow{2}{*}{$\begin{array}{c}\text { TIME } \\
(\mathbf{h r s})\end{array}$} & \multicolumn{7}{|c|}{ FORMULATION CODE } \\
\cline { 2 - 7 } & F7 & F8 & F9 & F10 & F11 & F12 \\
\hline $\mathbf{0 . 5}$ & $16.2 \pm 0.2$ & $15.5 \pm 0.4$ & $15.2 \pm 0.4$ & $9.5 \pm 0.5$ & $12.2 \pm 0.1$ & $9 \pm 0.2$ \\
\hline $\mathbf{1}$ & $24.5 \pm 0.1$ & $24 \pm 0.3$ & $24.3 \pm 0.1$ & $16.3 \pm 0.2$ & $14.3 \pm 0.4$ & $13.5 \pm 0.3$ \\
\hline $\mathbf{2}$ & $36.2 \pm 0.6$ & $35.2 \pm 0.3$ & $34.9 \pm 0.3$ & $25.1 \pm 0.3$ & $26.6 \pm 0.5$ & $23.8 \pm 0.5$ \\
\hline $\mathbf{3}$ & $47.6 \pm 0.4$ & $44.9 \pm 0.1$ & $45.4 \pm 0.4$ & $34.7 \pm 0.3$ & $32.2 \pm 0.4$ & $32 \pm 0.4$ \\
\hline $\mathbf{4}$ & $60.4 \pm 0.6$ & $60.1 \pm 0.3$ & $59.4 \pm 0.3$ & $43.7 \pm 0.5$ & $38.9 \pm 0.6$ & $41.4 \pm 0.1$ \\
\hline $\mathbf{5}$ & $70.2 \pm 0.3$ & $70.4 \pm 0.3$ & $69.2 \pm 0.3$ & $53.4 \pm 0.1$ & $45.1 \pm 0.5$ & $45.4 \pm 0.5$ \\
\hline $\mathbf{6}$ & $81.8 \pm 0.4$ & $82.3 \pm 0.2$ & $81.8 \pm 0.4$ & $62.3 \pm 0.1$ & $57 \pm 0.1$ & $53 \pm 0.1$ \\
\hline $\mathbf{7}$ & $95.6 \pm 0.5$ & $95.3 \pm 0.5$ & $95.3 \pm 0.5$ & $67.8 \pm 0.1$ & $66.2 \pm 0.3$ & $60.9 \pm 0.2$ \\
\hline $\mathbf{8}$ & $106 \pm 0.1$ & $104 \pm 0.1$ & $104 \pm 0.1$ & $71.7 \pm 0.2$ & $68.8 \pm 0.4$ & $66.5 \pm 0.3$ \\
\hline $\mathbf{9}$ & - & - & - & $74.8 \pm 0.6$ & $75.2 \pm 0.8$ & $72.1 \pm 0.2$ \\
\hline $\mathbf{1 0}$ & - & - & - & $87.2 \pm 0.3$ & $86.6 \pm 0.6$ & $80.2 \pm 0.1$ \\
\hline $\mathbf{1 1}$ & - & - & - & $97.7 \pm 0.2$ & $94.3 \pm 0.6$ & $90.2 \pm 0.5$ \\
\hline $\mathbf{1 2}$ & - & - & - & $102.9 \pm 0.3$ & $98 \pm 0.4$ & $97.1 \pm 0.2$ \\
\hline
\end{tabular}

Table 9: Cumulative \% drug release of formulations F13 to F18

\begin{tabular}{|c|l|l|l|l|l|l|}
\hline \multirow{3}{*}{$\begin{array}{c}\text { TIME } \\
\text { (hrs) }\end{array}$} & \multicolumn{7}{|c|}{ CUMULATIVE \% DRUG RELEASE } \\
\cline { 2 - 6 } & $\mathbf{F 1 3}$ & $\mathbf{F 1 4}$ & \multicolumn{1}{|c|}{ F15 } & \multicolumn{1}{c|}{ F16 } & F17 & F18 \\
\hline $\mathbf{0 . 5}$ & $5.7 \pm 0.2$ & $5.7 \pm 0.2$ & $8.7 \pm 0.5$ & $8 \pm 0.2$ & $12.5 \pm 0.1$ & $9.2 \pm 0.2$ \\
\hline $\mathbf{1}$ & $10.2 \pm 0.4$ & $7 \pm 0.4$ & $9.8 \pm 0.4$ & $10.7 \pm 0.4$ & $17.7 \pm 0.3$ & $12.8 \pm 0.1$ \\
\hline $\mathbf{2}$ & $18 \pm 0.2$ & $20 \pm 0.3$ & $20.6 \pm 0.3$ & $18.8 \pm 0.2$ & $25.9 \pm 0.3$ & $20.3 \pm 0.4$ \\
\hline $\mathbf{3}$ & $30.1 \pm 0.4$ & $27.9 \pm 0.5$ & $27.9 \pm 0.6$ & $28.2 \pm 0.4$ & $36.5 \pm 0.6$ & $25.7 \pm 0.3$ \\
\hline $\mathbf{4}$ & $41.3 \pm 0.3$ & $40 \pm 0.2$ & $40.8 \pm 0.2$ & $39.3 \pm 0.4$ & $43.5 \pm 0.2$ & $32.8 \pm 0.4$ \\
\hline $\mathbf{5}$ & $54.8 \pm 0.1$ & $46.5 \pm 0.5$ & $50.8 \pm 0.5$ & $50.8 \pm 0.3$ & $52.2 \pm 0.4$ & $45.5 \pm 0.5$ \\
\hline $\mathbf{6}$ & $60.7 \pm 0.3$ & $54.1 \pm 0.1$ & $59.9 \pm 0.2$ & $56.7 \pm 0.1$ & $56.6 \pm 0.1$ & $59.4 \pm 0.1$ \\
\hline $\mathbf{7}$ & $69.2 \pm 0.3$ & $58.6 \pm 0.6$ & $63.7 \pm 0.1$ & $68.6 \pm 0.4$ & $61.8 \pm 0.1$ & $65.3 \pm 0.4$ \\
\hline $\mathbf{8}$ & $75.8 \pm 0.6$ & $64.9 \pm 0.3$ & $70.8 \pm 0.3$ & $80.3 \pm 0.2$ & $68.6 \pm 0.4$ & $71.4 \pm 0.2$ \\
\hline $\mathbf{9}$ & $87.5 \pm 0.5$ & $84 \pm 0.4$ & $83.6 \pm 0.4$ & $86.7 \pm 0.3$ & $83 \pm 0.3$ & $79.8 \pm 0.3$ \\
\hline $\mathbf{1 0}$ & $92.9 \pm 0.2$ & $91.7 \pm 0.2$ & $89.3 \pm 0.2$ & $92.2 \pm 0.2$ & $91 \pm 0.3$ & $88.8 \pm 0.2$ \\
\hline $\mathbf{1 1}$ & $100 \pm 0.3$ & $98.9 \pm 0.4$ & $98.8 \pm 0.4$ & $98.9 \pm 0.2$ & $97.9 \pm 0.2$ & $97.5 \pm 0.2$ \\
\hline $\mathbf{1 2}$ & $106.7 \pm 0.1$ & $105 \pm 0.1$ & $105 \pm 0.1$ & $104 \pm 0.4$ & $103 \pm 0.4$ & $103 \pm 0.5$ \\
\hline
\end{tabular}

\section{Value are mean \pm SD $\mathbf{n}=3$}

In-vitro dissolution studies of all the formulations were carried out in $0.1 \mathrm{~N} \mathrm{HCl}$. The release of Nizatidine from floating bioadhesive tablets varied according to the type and concentration of polymer. Formulations F1 to F9 containing HPMC K4M showed faster drug release and entire drug was released within $8 \mathrm{~h}$ this might be due to the low viscosity of HPMC K4M polymer. While formulations F10 to F18 containing HPMC K15M showed constant drug release up to $12 \mathrm{~h}$. Formulation F14, F15, F16 containing HPMC K15M and Sodium CMC showed faster release than formulations F16, F17, F18 containing HPMC
$\mathrm{K} 15 \mathrm{M}$ and sodium alginate and F10, F11, F12 containing HPMC K15M and carbopol 934 this might be due to low viscosity of the sodium CMC polymer. And formulations F16, F17, F18 containing HPMC K15M and sodium alginate showed faster release than F10, F11, F12 formulations due to the low viscosity of sodium alginate when compared to carbopol 934p. It was also observed that as the concentration of carbopol $934 p$ was increased drug release was decreased. Thus as the concentration and viscosity of the polymer increases and release rate of the drug from the drug delivery system decreases. 


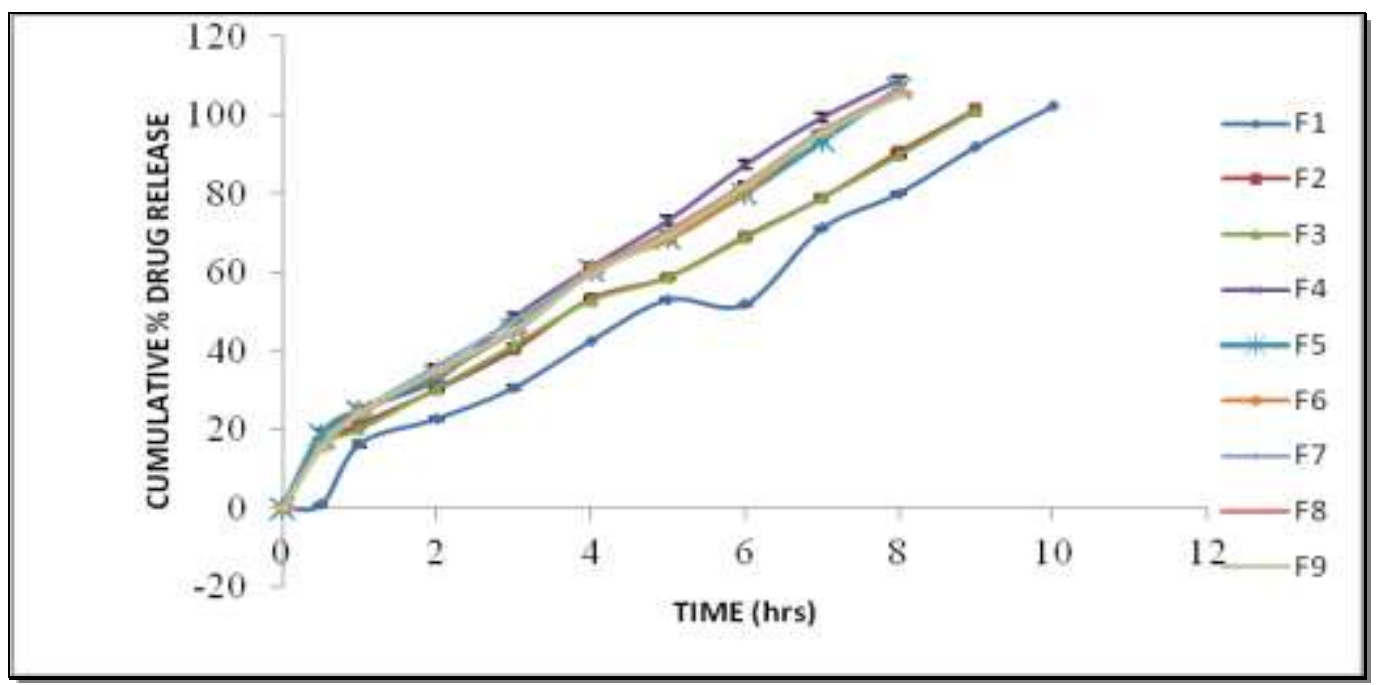

Figure 10: Cumulative \% drug release of F1 to F9 formulations

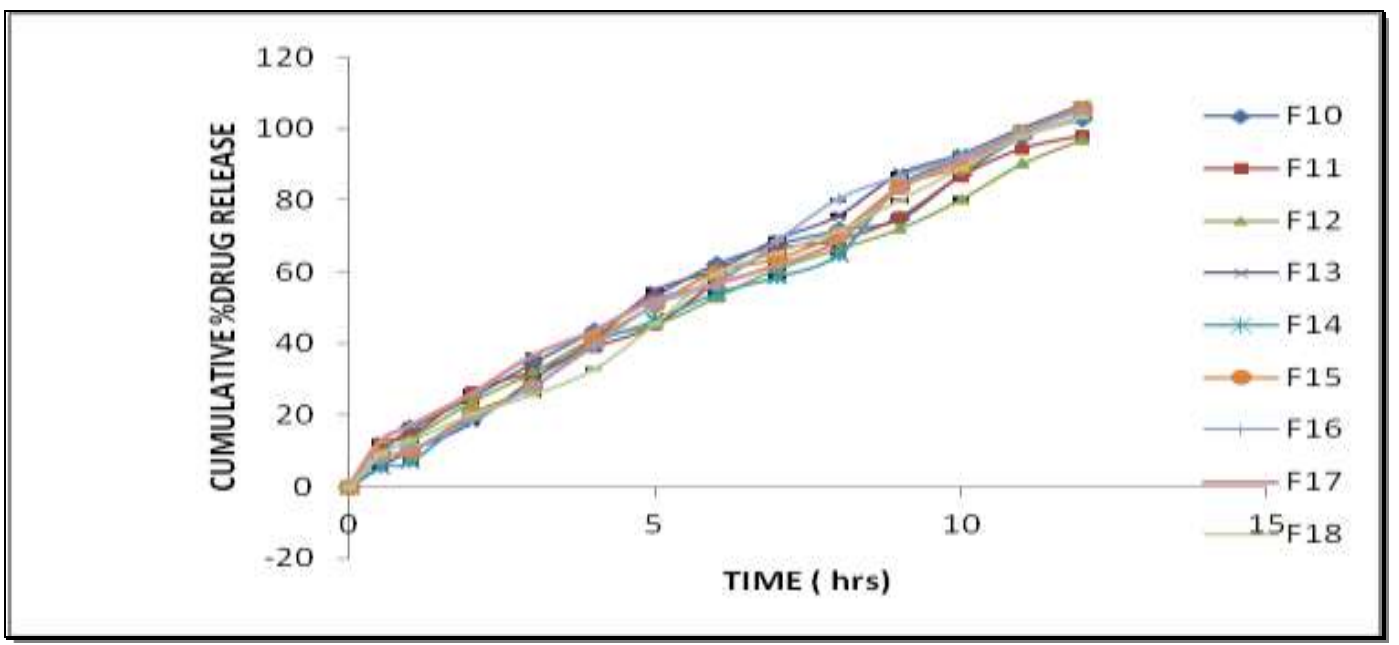

Figure 11: Cumulative \% drug release of F10 to F18 formulations.

Kinetic release studies:

Table 10: Kinetic release data of all formulations

\begin{tabular}{|l|l|l|l|l|c|}
\hline \multirow{2}{*}{$\begin{array}{c}\text { FORMULATION } \\
\text { CODE }\end{array}$} & $\begin{array}{l}\text { ZERO } \\
\text { ORDER }\end{array}$ & $\begin{array}{l}\text { FIRST } \\
\text { ORDER }\end{array}$ & \multicolumn{1}{|l|}{ HIGUCHI } & \multicolumn{2}{|l|}{ KORSMEYER PEPPAS } \\
\cline { 2 - 6 } & \multicolumn{1}{|c|}{$\mathbf{R}^{\mathbf{2}}$} & \multicolumn{1}{|c|}{$\mathbf{R}^{\mathbf{2}}$} & $\mathbf{R}^{\mathbf{2}}$ & $\mathbf{R}^{\mathbf{2}}$ & $\mathbf{n}$ \\
\hline F1 & 0.989 & 0.762 & 0.970 & 0.983 & 0.638 \\
\hline F2 & 0.990 & 0.741 & 0.966 & 0.981 & 0.649 \\
\hline F3 & 0.990 & 0.733 & 0.969 & 0.983 & 0.650 \\
\hline F5 & 0.990 & 0.792 & 0.966 & 0.970 & 0.656 \\
\hline F6 & 0.989 & 0.797 & 0.962 & 0.975 & 0.637 \\
\hline F7 & 0.990 & 0.811 & 0.968 & 0.987 & 0.677 \\
\hline F8 & 0.990 & 0.822 & 0.976 & 0.992 & 0.674 \\
\hline F9 & 0.991 & 0.826 & 0.974 & 0.990 & 0.691 \\
\hline F10 & 0.991 & 0.818 & 0.974 & 0.991 & 0.690 \\
\hline F11 & 0.985 & 0.771 & 0.981 & 0.997 & 0.743 \\
\hline F12 & 0.991 & 0.863 & 0.970 & 0.9824 & 0.696 \\
\hline F13 & 0.992 & 0.908 & 0.977 & 0.997 & 0.750 \\
\hline F14 & 0.992 & 0.795 & 0.985 & 0.997 & 0.940 \\
\hline F15 & 0.993 & 0.722 & 0.962 & 0.986 & 0.960 \\
\hline F16 & 0.995 & 0.738 & 0.742 & 0.982 & 0.853 \\
\hline F17 & 0.990 & 0.811 & 0.968 & 0.987 & 0.677 \\
\hline F18 & 0.990 & 0.822 & 0.976 & 0.992 & 0.674 \\
\hline
\end{tabular}


The kinetics of drug release was examined by plotting the data obtained from in-vitro drug dissolution studies in various kinetic models such as Zero-order, First order, Higuchi release model and Korsmeyer and Peppas model. From results it is concluded that in-vitro drug release followed zero order release kinetics and the drug release mechanism was found to be of non-Fickian type.

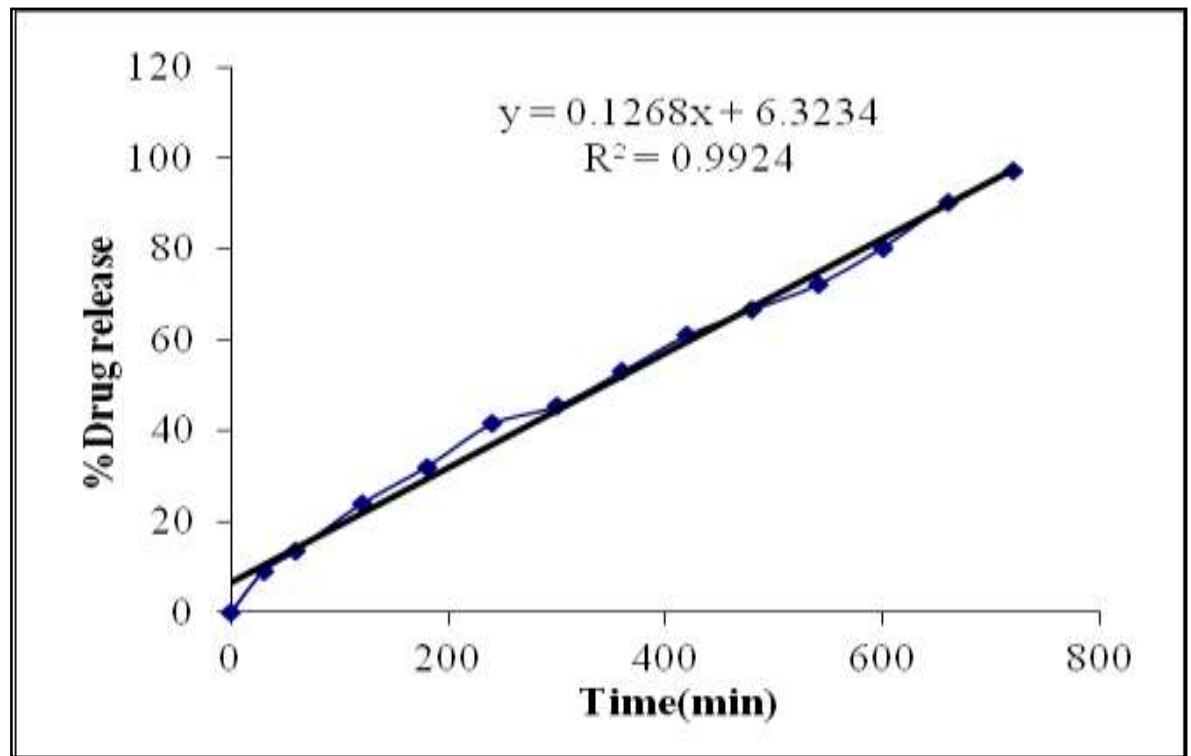

Figure 12: Cumulative \% drug released v/s Time for the optimized formulation ( Zero order rate)

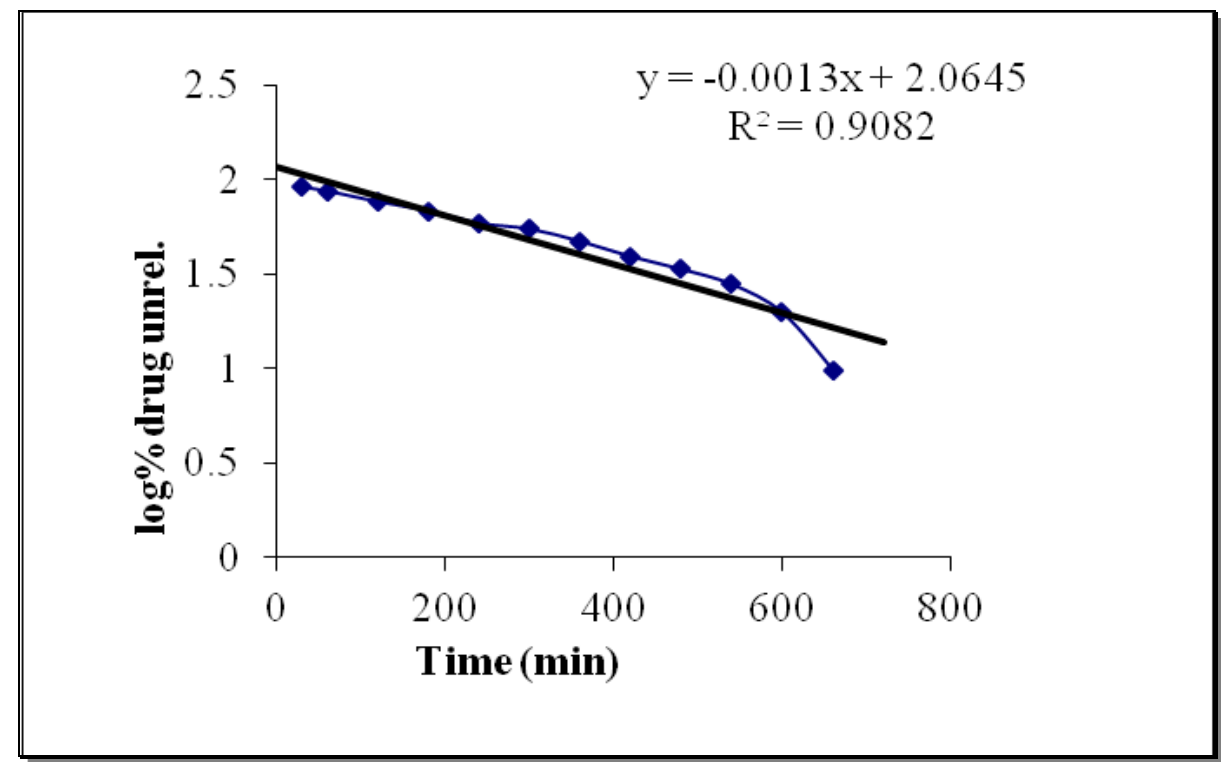

Figure 13: Log cumulative \% drug unreleased v/s Time for the optimized formulation ( First order rate) 


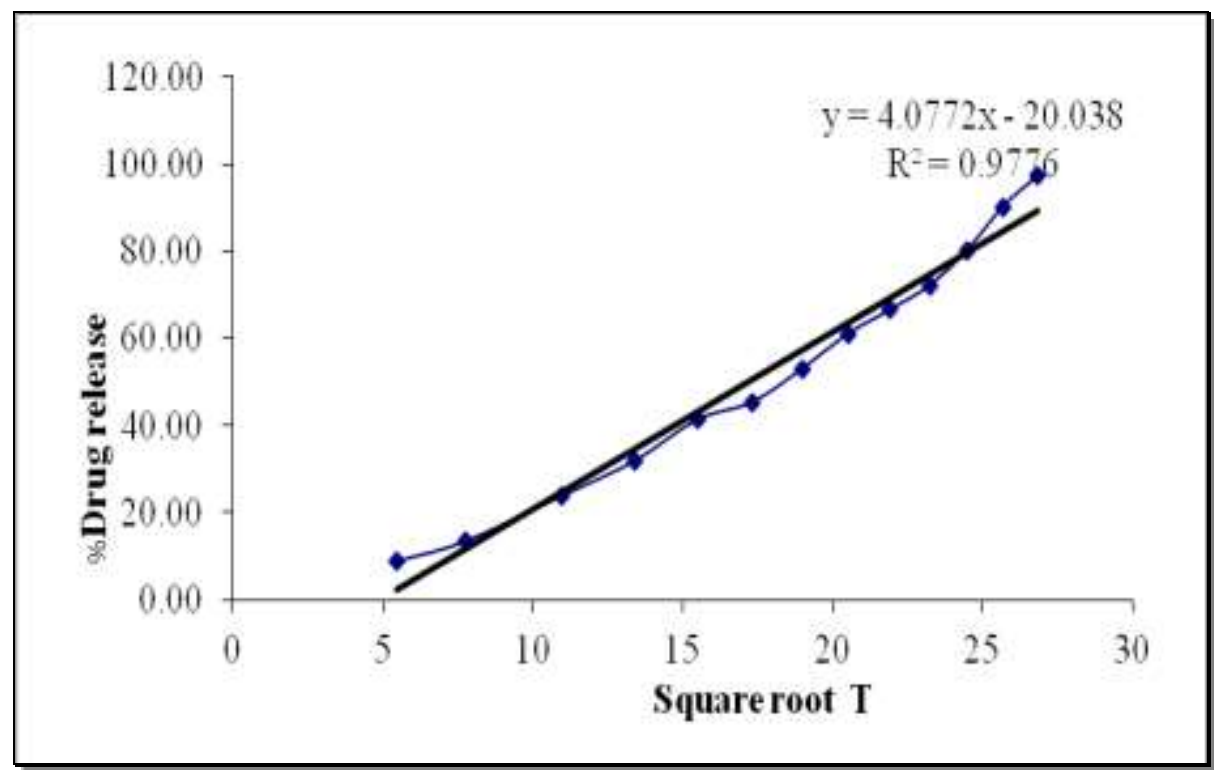

Figure 14: Cumulative \% drug released v/s Root time for the optimized formulation ( Higuchi matrix)

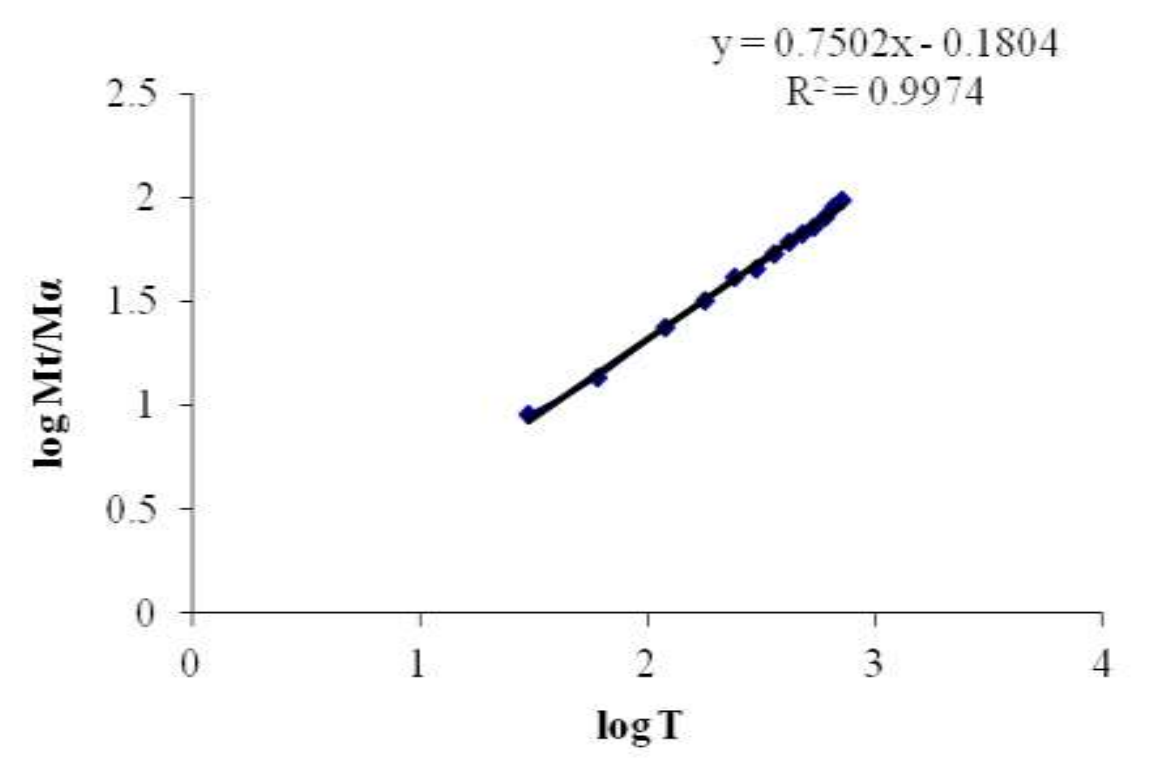

Figure 15: Log cumulative \% drug released v/s Log time for the optimized formulation ( Peppas model)

\section{CONCLUSION}

Floating-bioadhesive tablets of Nizatidine can be prepared by direct compression method using HPMC K4M, HPMC K15M, Sodium CMC, Sodium alginate and Carbopol 934P polymers. IR spectroscopic studies indicated that there are no drug- excipient interactions. As the concentration of HPMC K4M and HPMC K15M decreases, the floating lag time increases. As the concentration and viscosity of polymer in the tablet increases, the drug release rate decreases, whereas swelling index and the bioadhesion strength increases.All the designed formulations displayed zero order release kinetics and drug release follows non-Fickian diffusion mechanism. Among all the formulations, F12 formulation containing 3:1 ratio of HPMC $\mathrm{K} 15 \mathrm{M}$ and Carbopol 934P was found to be promising, which showed a floating lag time less than $5 \mathrm{~min}$ and floating duration of more than 12 hours. It showed a constant drug release upto 12 hours and good bioadhesion strength. Hence, this F12 formula can be brought to the market successfully. 


\section{REFERENCES}

1. Sauzet, C., Claeys, B.M., Nicolas, M., An innovative floating gastro-retentive dosage system: formulation and in-vitro evaluation, Int J Pharm Sci 2009; 23-29.

2. Anand, S.S., Rakhee, K.K., An overview on various approaches to oral controlled drug delivery system via gastric retention, Int J Pharm Sci., 2010; 2: 68-72.

3. Deshpande, Shah, N.H., Rhodes, C.T., Malick, A.W., Development of a novel Controlled release system for gastric retention, Pharm. Res., 1997; 14: 815-19.

4. Shweta, A., Javed, A., Alka, A., Roop, K.K., Sanjula,B., Floating drug delivery systems: a review, APPS Pharm Sci Tech., 2005; 6: 372-390.

5. Zate, S.U., Kothawade, Mahale, G.H., Kapse, K.P., Anantwar, S.P., Gastroretentive bioadhesive drug delivery system. Int J of Pharm tech research., 2010; 2: 1227-35.

6. Jain, N.K., Progress in controlled and novel drug delivery systems, CBS publishers and distributors, 2005; 76-81.

7. Davis, S.S., Stockwell, A.F., Taylor, M.J., The effect of density on the gastric emptying of single- and multiple- unit dosage forms, Pharm Res., 1986; 3: 208-213.

8. Singh, S., Joshi, V., Barpete, P. K., Gastroretentive drug delivery System: current approaches. Journal of Pharmacy Research., 2009; 2: 881-86.

9. Debjit, B., Chiranjib, B., Margret, C., Jayakar, B., Sampath, K.K.P., Floating drug delivery system. Der Pharmacia Lettre., 2009; 2: 199-218.

10. Vinod, K.R., Santhosh, V., Anubuazaghan, S., David, B., Padmasri, A., Sandhya, S., Approaches for gastroretentive drug delivery system., 2010; 2: 589-601.

11. Amit, K.N., Ruma, M., Biswarup, D., Gastroretentive drug delivery system, A Review.,2010; 3(1): 210.

12. Gholap, S.B., Banarjee, S.K., Gaikwad, D.D., Gaikwad, S.L., Jadhav, R.M., Hollow microsphere, A Review., 2010; 1(1): 74-79.

13. Pradeep, K., Deepika, J., Vikas, J., Floating drug delivery systems: An overview. Journal of Pharmacy Research., 2010; 3: 1274-79.

14. Garg, R., Gupta, G.D., Progress in controlled gastroretentive delivery systems Journal of Pharmaceutical Research., 2008; 7: 1055-66.

15. Samyuktha, R.B., Vedha, H.B.N., Brahma, R.A., Punitha, S., Parimala, D., The recent developments on gastric floating drug delivery system: An overview, Int J of Pharm tech research., 2010; 2: 524-534. 